\title{
Students Collaboration Skills in Science Learning
}

\author{
Silfia Ilma ${ }^{1,2}$, Mimien Henie Irawati Al-Muhdhar ${ }^{3}$, Fatchur Rohman ${ }^{3}$, Murni \\ Saptasari $^{3}$
}

\begin{abstract}
${ }^{1}$ Postgraduate doctoral student of biologi education study program Postgraduate Program Malang State University, Jl.Semarang No 5 Sumbersari, Kec. Lowokwaru, Malang 65145, Indonesia

${ }^{2}$ Program study of Biology education Faculty of teacher training and education University of Borneo Tarakan, Jl.Amal Lama No 1, Tarakan 77123, Indonesia

${ }^{3}$ Departement of biology Faculty of Mathematics and natural science Malang State University, Jl. Cakrawala No 5 Sumbersari, Kec.Lowokwaru, Malang 65145, Indonesia

Corresponding author: mimien.henie.fmipa@um..ac.id
\end{abstract}

\begin{abstract}
Collaboration skills are skills that students must possess to face the challenges of the 21 st century. Collaboration skills do not only play a role in learning but are indispensable for solving life problems. The purpose of this study was to identify the collaboration skills of high school students in science learning. This non-experimental survey research involved 226 high school students. Data collection was carried out by observation with observation guidelines. The aspects of collaboration skills that we observe are work productively, demonstrate respect, compromise, and shared responsibility. The results showed that the highest level of productive collaboration skills in working at level 2 basic category was $55.71 \%$. shown the highest award at level 2 basic category of 54.29\%. The highest compromise was at level 1 for the novice category at $55.91 \%$. the highest share responsibility at level 1 for the novice category of $51.43 \%$. In general, collaboration skills in student learning need to be improved. Based on the results of this study, a learning model is needed that can empower students' collaboration skills.
\end{abstract}

Keywords: Collaboration skills, science learning, students, senior high school

\section{INTRODUCTION}

The 21 st century provides fundamental changes, in various aspects of life. Everyone is required to have good thinking skills and social attitudes. Technological progress demands collaboration as an absolute requirement that must be had to survive in a better life in the era of globalization [1]. One way to initiate collaboration skills is through learning.

21st-century learning must be able to lead students to think at higher levels and have good collaboration skills [2]. Collaboration skills are a requirement for success in global competition [3, 4]. Networking is important to achieve the desired goals. Collaboration skills allow a person to solve problems faced together, by involving various roles, positive interactions, and interdependence [5]. Collaboration skills need to be prepared from an early age, especially through learning.

Collaboration skills teach students to interact with peers in learning activities. This facilitates students in the development of cognition and knowledge acquisition. Collaboration skills can develop students' thinking and problem-solving skills [3] besides that collaboration skills are also able to improve performance $[2,15]$, can mobilize and give positive energy to others [6] facilitate the work of others, and be able to identify the abilities of team members [7]. Another study adds that collaboration skills can train students to work together in planning, group decision making, setting goals, setting time, accepting roles, and creating a positive group environment, as well as increasing learning effectiveness [8].

The obstacles faced by practicing student collaboration skills in schools are context, content, educators, and students [9]. Collaboration skills are not just a means to develop or evaluate knowledge learned through engagement in learning and practice $[8,10]$. To develop student collaboration skills, a learning model is needed that can facilitate students to interact with each other, work together to solve group problems, share, and take responsibility together. 
Students' collaboration skills in science learning have not been widely disclosed, especially in high schools. The results of interviews with science teachers indicate that the learning that has been taking place so far emphasizes cognitive learning outcomes, while the aspects of collaboration skills have not been fully empowered. Collaboration skills in science learning are a driving force so that students can find comprehensive science concepts and solve scientific problems in a solution $[11,14,16]$. The results of previous research conducted by Sari [17] at junior high school indicated that students' collaboration skills in science learning were still low. The same thing was also reported by Stuner, Bishop, \& Lenhart [18] that students' collaboration skills still need to be empowered in science learning. Therefore it is important to explore the extent of students' collaboration skills, especially in science learning. This is the novelty of this study.

The benefits of collaboration skills are an effective division of labor, integration of information from various sources of knowledge, perspectives, and experiences, as well as increased creativity and quality of solutions combined with group ideas [8]. Collaboration skills can also improve social competence, conflict resolution skills, and academic self-concept $[12,19]$. Based on the description above, it is important to practice student collaboration skills in learning activities. This study aims to identify student collaboration skills in science learning in high schools.

\section{METHODS}

\subsection{Research design}

A non-experimental survey design was used for data collection in this study. This survey aims to measure students' collaboration skills. Student collaboration skills are focused on biology learning.

\subsection{Participants}

A non-probability convenience sampling approach was used to select students who would participate in this study. The student age range ranges from 14-16 years. Respondents in this study were 266 students who were in ten-grade senior high school.

\subsection{Instrumentations}

The collaboration skills observation sheet modified Greenstein (2012) [13], consists of 4 aspects, namely working productively, showing respect, compromise, and responsibility. The Cronbach's Alpha coefficient is 0.76> 0.11, this figure shows that the instrument that has been compiled is valid and reliable.

\subsection{Data Collection}

Student collaboration skills data are given a score of 14 , provided the description is in the rubric (Table 1.)

Table 1. Rubric of Students Collaboration Skills

\begin{tabular}{|c|c|c|}
\hline $\begin{array}{c}\text { Aspects of } \\
\text { Collaboration Skill }\end{array}$ & Score \& Category & Descriptors \\
\hline Works productively & $\begin{array}{l}4 \text { (Exemplary) } \\
3 \text { (Proficient) } \\
2 \text { (Basic) } \\
1 \text { (Novice) }\end{array}$ & $\begin{array}{l}\text { Usethe whole timeefficientlyto remainfocus on the taskand } \\
\text { producethat jobrequired.Every membergroup to dohis job. } \\
\text { Doing cooperation well andmost of thepermanentdoassignment } \\
\text { upteam memberscompleteprofession.Every member of the } \\
\text { team didalmost allthat taskassigned. } \\
\text { Sometimesworkingtogether, butnot allteam } \\
\text { memberscontributeor dohis job,making it difficultto } \\
\text { completeprofession. } \\
\text { Notcooperatewell.All membersof the team wants } \\
\text { doing thingsthemselvesand tellother team members what } \\
\text { shoulddoneso it's notfocusing on the task. }\end{array}$ \\
\hline $\begin{array}{l}\text { Demonstrate } \\
\text { respect }\end{array}$ & $\begin{array}{l}4 \text { (Exemplary) } \\
3 \text { (Proficient) } \\
2 \text { (Basic) } \\
1 \text { (Novice) }\end{array}$ & $\begin{array}{l}\text { All team members respectfully listened to and described the } \\
\text { ideas shared. } \\
\text { Most of the team members listened and interacted with respect. } \\
\text { Some team members have difficulty appreciating other people's } \\
\text { ideas. } \\
\text { Team members don't want to listen to other people and argue } \\
\text { with teammates. }\end{array}$ \\
\hline Compromise & 4 (Exemplary) & All team members are flexible in working together to achieve \\
\hline
\end{tabular}




\begin{tabular}{|l|l|l|}
\hline & $\begin{array}{l}\text { common goals. } \\
2 \text { (Broficient) }\end{array}$ & $\begin{array}{l}\text { Most group members work together in completing group work. } \\
\text { Several group members work together in completing group } \\
\text { work. } \\
\text { All group members do not cooperate in completing group work. }\end{array}$ \\
\hline Share responsibility & $\begin{array}{l}1 \text { (Exemplary) } \\
\text { All team members do their best work and follow the assigned } \\
\text { tasks. } \\
\text { Most of the team members work on the assigned task. } \\
\text { Several team members were involved in group work. } \\
1 \text { (Novice) }\end{array}$ & \begin{tabular}{l} 
All team members are not involved in group work. \\
\hline
\end{tabular} \\
\hline
\end{tabular}

Source: Modified Greenstein (2012)

\subsection{Data Analysis}

The profile data of collaboration skills were analyzed using descriptive statistics.

\section{RESULT DISCUSSION}

Data regarding students collaboration skills in biology learning is presented in Table 2.

Table 2.Students creativity

\begin{tabular}{|c|l|c|c|c|c|}
\hline No & \multicolumn{1}{|c|}{$\begin{array}{c}\text { Aspects of } \\
\text { collaboration skills }\end{array}$} & $\begin{array}{c}\text { Level 1 } \\
\text { (Novice) }\end{array}$ & $\begin{array}{c}\text { Level 2 } \\
\text { (Besic) }\end{array}$ & (Proficient) & (Exemplary) \\
\hline 1. & Works productively & 20.00 & 55.71 & 18.57 & 4.29 \\
2. & Demonstrated respect & 14.29 & 54.29 & 25.71 & 5.71 \\
3. & Compromise & 55.91 & 32.86 & 1.43 & 0.00 \\
4. & Share responsibility & 51.43 & 35.71 & 2.86 & 0.00 \\
\hline
\end{tabular}

Based on the data in Table 2 it is known that the highest works productively students in science learning are still in the basic category, namely $55.71 \%$, which means that only a few students can do work productively. This shows that there is still a need to empower students' work productively skills in science learning. Works productively students can be developed well if facilitated by collaborative learning such as project-based learning, problem-based learning, or inquiry learning. Unfortunately, science learning is currently still only concerned with memorizing it has not reached a higher realm of cognition.

Productive work in science learning can be done with a balanced group division of labor [15] so that social jealousy does not occur in completing work. For example, making productive observations, then discussing the results of the observations, and compactly discussing them with group members. The results of the observation showed that there were only a few group members at least 1 to 3 people (each group consisting of 5-6 students) who were actively involved. Meanwhile, other group members were not involved. In productive work, it is necessary to have 1 leader in each group, who can coordinate group members to achieve common goals. The results of this study are supported by Lai [10], Pang, Lau, Seah, Cheong, and Low, [15] who reported that not all group members can fully contribute to problem-solving, this is because the academic knowledge possessed by each student is different. Productive work can improve student academic achievement, social skills, and student psychology [12]. The awareness to advance is very necessary to produce productive work.

The highest student demonstration respect was in the basic category, namely $54.29 \%$, which means that some group members had difficulty appreciating other people's opinions. This shows that students have not been trained to respect the opinions of friends, and have not been able to express ideas well. Students demonstrated respect related to students' communication skills, related to good sentence formation in expressing opinions, and choosing appropriate words to make rebuttals in academic discussion forums. Student demonstrated respect can be trained through collaborative learning and cooperative learning.

Science learning instills in students to respect each other, this is better known as a scientific attitude 
[17]. Mutual respect in learning science is a form of tolerance both with living and inanimate things. Mutual respect can be done in various ways, from using correct spelling and pronunciation to providing an overview of a deep understanding of a concept [16]. The results of the observation showed that students had difficulty respecting each other. The results of this study are supported by Juceviciene, \&Vizgirdaite[9],Retnowati, Ayres, \&Sweller[12] who reported that students have not been able to show mutual respect in class discussions. This is because students are not used to speaking or conveying their aspirations in class. Students are used to learning to write and answer questions so that mutual respect has not been seen in learning.

The next aspect is compromised, the highest in the novice category, namely $55.91 \%$, which means that all group members are unable to make compromises to complete group assignments. this shows that students are still individualistic in solving group problems. Compromises can be increased through project learning activities, problem-based learning, or cooperative learning activities.

Compromise in science learning can be shown through decision-making activities in formulating problems, making hypotheses, or making decisions. Unfortunately, this has not yet appeared in science learning. Students focus on their worksheets. Students need higher motivation to make compromises in achieving common goals [7]. The results of this study are supported by Pang, Lau, Seah, Cheong, \& Low [15], Evans [2] who reports that in science learning it is necessary to train in compromises to achieve common goals.

The highest share of student responsibility in the novice category is $51.43 \%$, which means that all group members are not responsible for group assignments. The results of the observations show that students collect assignments, not with their groups. Only 2 groups were willing to collect the task together with the group at the agreed time. The results of this study are supported by Rimoni\& Averill [16], O'Leary, Choi, \& Gerard [6] who reported that the students' low responsibility towards groups was due to a lack of coordination in problem-solving. Student share responsibility can be empowered through collaborative and cooperative learning.

Based on the survey results (Table 2), the collaboration skills of high school students on science learning in general, from four aspects, still need to be empowered. Several previous studies have also reported low student collaboration skills in science learning [14, 11]. Science learning should be able to foster student collaboration skills if it is carried out through scientific activities such as practicum or experiments. Miller [19] also explains that science learning can generate collaborative and problem-solving skills if it is done by actively involving students. Collaboration skills involve various abilities from several fields, so students must have a knowledge base to start collaborating in solving problems [18].

\section{CONCLUSION}

The conclusion in this study is that in general the profile of students' collaboration skills in science learning still needs to be improved, this is based on the results of research which show the low level of student collaboration skills, namely productive collaboration skills in working at level 2 basic category was $55.71 \%$. shown the highest award at level 2 basic category of $54.29 \%$. The highest compromise was at level 1 for the novice category at $55.91 \%$. the highest share responsibility at level 1 for the novice category of $51.43 \%$.

Student collaboration skills can be empowered through collaborative learning and cooperative learning. However, to empower students' collaboration skills, teachers need understanding and awareness of the importance of collaboration skills for students to face the challenges of the 21 st century.

\section{ACKNOWLEDGMENTS}

Thank you to the education office of the city of Tarakan, the principal of the 1 state senior high school of the city of Tarakan, and the principal of the 3 state high school of the city of Tarakan who have given permission and facilitated researchers to survey this research.

\section{REFERENCES}

[1] A. N. Lay andK. Osman, "Developing 21st century chemistry learning through designing digital games,"Journal of Education in Science, Environment and Health (JESEH), vol. 4, no.1,pp. 81-92, 2018.

[2] C. M. Evans, "Measuring student success skills: A Review of the Literature on Collaboration $21^{\text {st }}$ Century Succes Skills,"National Center for the Improvement of Educational Assessment, 2020.

[3] H. Boholano, "Smart Social Networking: 21st Century Teaching and Learning Skills, Research in Pedagogy,"vol. 7(1), Serbian Academy of Education, vol. 7, no. 1, pp. 21-29, 2017.

[4] J. W. Pallegrino, "Assessment as a positive influence on 21 st century teaching and learning: A systems approach to progress, 
PsicologiaEducativa," vol. 20, no. 2, pp. 65-77, 2014.

[5] A. Sahin, M. C. Ayar, and T.Adiguzel, " STEM Related After-School Program Activities and Associated Outcomes on Student Learning,"Educ.Sci.: Theory and Practice, vol. 14, no. 1, pp. 309-322, 2014.

[6] R. O‘Leary, Y. Choi, and C. M. Gerard, "The Skill Set of the Successful Collaborator,"Public Administration Review, vol. 72(SUPPL.1), pp. 83-84, 2012.

[7] R. Keast, and M. P.Mandell, "Collaborative competencies/capabilities,"Australian Research Alliance for Children and Youth (ARACY), 2013.

[8] D. Kuhn, "Thinking together and alone, Educational Researcher," vol. 44, no. 1, pp. 4653, 2015.

[9] P. Juceviciene, and J.Vizgirdaite "Educational Empowerment of Collaborative Learning at the University,"Social Sciences, vol. 75, no. 1, pp. 41-52, 2012.

[10] E. R. Lai, "Collaboration: A Literature Review,'Pearson, 2011.

[11] R. M. Yasin, L. Amin, and K. K.Hin, "Teaching \& Learning of 21st Century Biotechnology in Secondary School Additional Science,'Teaching Science, vol. 64, No. 3, pp. 27-36, 2018.

[12] E. Retnowati, P. Ayres, and J.Sweller, "Can collaborative learning improve the effectiveness of worked examples in learning mathematics?,"J. Educ. Psy., vol. 109, pp.666-679,2017.

[14] N. Hidayati, "Collaboration Skill of Biology Students at Universitas Islam Riau, Indonesia," Int. Journalof Scientific \& Technology Research, vol. 8. No. 11, pp. 208-211, 2019.

[13] L. Greenstein, "Assessing $21^{\text {st }}$ Century Skills: A Guide to evaluating Mastery and Authentic Learning," California: Corwin A Sage Company, 2012.

[15] Pang, J. Lau, C. P. Seah, L. Cheong,andA. Low, "Socially Challenged Collaborative Learning of Secondary School Students in Singapore," Educ.Sci., vol. 8, no. 24, 2018.

[16] F. Rimoni, and R. Averill, "RESPECT: A Value Vital for Pasifika Learners," Research Information for Teachers, vol. 3, pp. 3-11, 2019.

[17] E. R. Sari, M.Haviz, andAfwadi, "Model of Tolerance in Class VIII Science Learning of AlhiraPramuka Islamic Boarding School, Padang Panjang,"Biosphere: Journal of Biological Education, vol. 10, no. 1, 2017.

[18] K. K. Stuner, P. Bishop, and S. M. Lenhart, "Developing Collaboration Skills in team undergraduate research Experiences,"PRIMUS, vol. 27, no. 3, pp. 370-388, 2017.

[19] J. Miller, "The Physics of Sound,"Science and Children, vol. 54, no. 4, pp. 34-40, 2016. 